\title{
Sidama Agro-Pastoralism and Ethnobiological Classification of its Primary Plant, Enset (Ensete ventricosum)
}

\author{
Marsha B. Quinlan ${ }^{1 *}$, Robert J. Quinlan ${ }^{1}$, and Samuel Jilo Dira ${ }^{1,2}$
}

Author address: ${ }^{1}$ Department of Anthropology, Washington State University, Pullman, WA, USA. ${ }^{2}$ Department of Behavioral Science, Anthropology Program, Hawassa University, SNNPRS, Ethiopia.

*Corresponding author: mquinlan@wsu.edu

Received: July 01, 2014

Volume: 5:116-125

Published: October 2, 2014

(C) 2014 Society of Ethnobiology

\begin{abstract}
Enset is an essential plant for the Ethiopian Sidama system of agropastoralism. Sidama agropastoralism and the folk taxonomy of enset is presented here in ethnographic context. One of several societies of Ethiopia's enset complex, the highland Sidama are among the most wholly reliant on enset and maintain more enset varieties in their gardens than other groups. Sidama agro-pastoral systems revolve around human-enset-cattle interaction: Sidama eat low-protein parts of enset; cattle eat high-protein parts of enset; Sidama get protein from dairy; Sidama fertilize enset with cattle manure. In the Sidama language, enset offers an example of Hunn's generic elevation within the framework of Berlinian perceptualtaxonomic theory. Weesho (enset) may serve both as a folk generic taxon and a life-form taxon depending on the frame of reference. Such expansion allows for an intermediate taxa translating to "male" or "female" ensets, followed by generic and specific taxa for kinds or "breeds" of enset. Generic elevation offers descriptive magnification of nomenclature for enset, a most salient species among Sidama people.
\end{abstract}

Keywords: East Africa, Linguistic Ethnobiology, Musaceae, Ethnobotany, Pastoralism

This letter discusses Sidama folk taxonomy of enset [Ensete ventricosum (Welw.) Cheesman 1 ], an important root and stem staple in the horn of Africa, in the highlands and midlands of Southern Ethiopia. The enset plant feeds millions of Ethiopians, and is central to Sidama agro-pastoralism. Sidama people eat enset daily, sleep on its fibers as mattress stuffing nightly, and use it for numerous other purposes, including feeding their treasured cattle. It is, perhaps unsurprising that in the Sidama language, enset description would contain specificity requiring a generic elevation (sensu Hunn 2013) of the Berlinian (e.g. Berlin 1992) framework of folk biological classification.

Using cross-linguistic data, Brent Berlin and colleagues developed a universal framework for folk biological classification (see notably Berlin 1973, 1992; Berlin et al.1966, 1973). This standard Berlinian framework contains six ranks of taxonomic inclusion, progressing as follows from most inclusive to most exclusive: unique beginner [or kingdom, e.g. 'plant'], life-form [e.g. 'tree'], generic [e.g. 'pine'], specific [e.g. 'white pine'], varietal [e.g. 'eastern white pine'], with a possible intermediate rank between life-form and generic levels [e.g. 'evergreen']. Eugene Hunn (1982) argued that classification is not purely perceptual but also reflects local culture in that language is utilitarian; and knowledge of a life-form reflects practical, adaptive cultural importance of that organism. Cecil Brown asserted that "vocabulary is to a large extent reflective of the long-term interests and endeavors of the people who use it" (Brown 1986: 3). He demonstrated that with subsistence differences and their associated divergences in attention to certain biota, shifts in nomenclature-expansion or restrictions of taxonomic ranks-may occur within the Berlinian classification framework (Brown 1985, 1986). Recently, Hunn (2013) used the example of English speakers' folk taxa for dogs to demonstrate how biota of particular cultural focus may require an expansive shift within the Berlinian framework. The term "dog," in addition to its position as a folk generic taxon, may serve more generally as a life-form taxon, depending on the frame of reference. Hunn coins the term "generic elevation" (see also Hunn and Brown 2011) for these circumstances in which generic taxa 'rise' to the life-form rank to allow more specificity to classify ethnobiologically important "kinds" of a species, as with "kinds" or "breeds" of dog among 
Americans in Hunn's example.

This perspective letter is based on descriptive, observational data and literature. We do not attempt to inventory each taxon for "kinds of enset" in the lexicon (see Bizuayehu 2008 for many terms). Rather, we use Berlinian ethnobiological classification, ethnography of Sidama subsistence behavior, and widespread subsistence vocabulary to examine how Sidama generic elevation of enset occurs on the ground, or, more accurately, in the garden. Our data is part of the larger Ethiopia Risk and Resilience project $^{2}$, on which we all participated during field seasons in 2012 (Robert Quinlan and Samuel Dira) 2013 (Samuel Dira, Marsha and Robert Quinlan), and for which all authors collected qualitative data concerning agricultural practices using open-ended ethnographic interviews with Sidama highlander key informants. We culled these interviews for enset terms and their usage. We compared and added our findings to those of Bizuayehu 2008. To find rankings, we asked Sidama people to clarify, regarding "kinds," asking, e.g., "Is B a kind of A?" (Berlin 1992). S.J.D. returned to Ethiopia in summer 2014 for his dissertation and was able to inquire with other Sidama (S.J.D. is a native Sidama Anthropologist) on particular questions of classification.

\section{Sidama Agro-Pastoralism and Enset Gardening} The Sidama belong to the East African "enset complex" (Shack 1966), which has received relatively little academic attention compared to the East African "cattle complex" system (Herskovitz 1926). The Horn of Africa, in addition to its pastoralism, has plantingbased subsistence traditions, broken into hoe (root) and plow (cereal) cultures (e.g. Murdock 1959, Westphal and Westphal-Stevels 1975). Within the hoe cultures, enset is "by far" the most important staple food (Murdock 1959), feeding a dense rural population across SW Ethiopia (see e.g. Bezuneh 1971, Bezuneh and Feleke 1966, Brandt et al. 1997, Rahmato 1995, Shack 1963). In Ethiopia, the pastoralist, hoe, and plow farming distinctions remain useful, but, on the ground, these are not simple, isolated strategies. In all but the driest lowlands, where herders grow no crops, and the highest altitudes, where enset thrives best (Pijls et al. 1995), people grow enset along with varying proportions of other root crops or cereals (see Brandt et al 1997, and R. Quinlan et al.n.d.). Shack (1963) concludes that the sedentarypastoral dichotomy is inadequate, and we concur. Planting co-exists with the cattle complex in the form of agro-pastoralism, such that the "enset complex," in reality entails a subsistence system of mutual dependence between humans, livestock, and crops.

Ensete ventricosum is native to Ethiopia, which is the center of its domestication and diversity (Vavilov 1951). The species is widely distributed in SubSaharan Africa (Simmonds 1962), yet only Ethiopians cultivate and use enset primarily as a food crop (Bezuneh 1971, Pijls et al. 1995, Simmonds 1962). Due to civil wars and other political instabilities in Ethiopia from 1974 through the 1990s, academic exchange and research on Ethiopian people and biota declined for many years, hence the culture of enset remains under-studied and obscure internationally relative to the size of the populations that subsist on it. Enset cultivation covers about 42,000 square miles of Ethiopia (Bezuneh and Feleke 1966) and supports a dense rural population ranging from 200 to over 400 people per square kilometer ( $\approx 322$ to $644 \mathrm{mi} 2)$, totaling well over 10 million people (Brandt et al. 1997) and Shank and Ertiro (1996) estimate up to 15 million. With this many people supported almost entirely by enset, we might expect local languages to distinguish and identify numerous enset types.

The Sidama are a Cushitic-speaking people inhabiting areas between the Rift Valley lakes of Awassa and Abaya in southwestern Ethiopia (Hamer 1987). Most Sidama reside in the Southern Nationalities, Nations, and Peoples Regional State (SNNPRS). As of the 2007 Census, the Sidama population of almost three million made them the fifth largest ethnic group in Ethiopia (CSAE 2013). Not only are the Sidama one of several societies that comprise Ethiopia's "enset complex," they are one of the two cultures-the Gurage being the other- that Ethiopians refer to as the quintessential enset cultures for which a good proportion of their communities rely on enset as their sole staple crop (see Brandt et al 1997). This research takes place in the Sidama highlands, the area most reliant on enset. The Sidama's primary food is waasa (wasa in I.P.A.), the starchy pulp from of enset leaves, stem and corm. Sidama eat waasa in two forms, either flattened and cooked as bread, called tima, or as a thick porridge called raisame. They complement these enset foods with butter, milk, or cabbage.

The Sidama agro-pastoral system revolves around human-enset-cattle interactions. Sidama raise zebu cattle, Bos primigenius indicus ${ }^{3}$. The pasture grass in the Sidama highlands is primarily Andropogon abyssinicus R.Br. ex Fresen., which many Ethiopian highlanders 


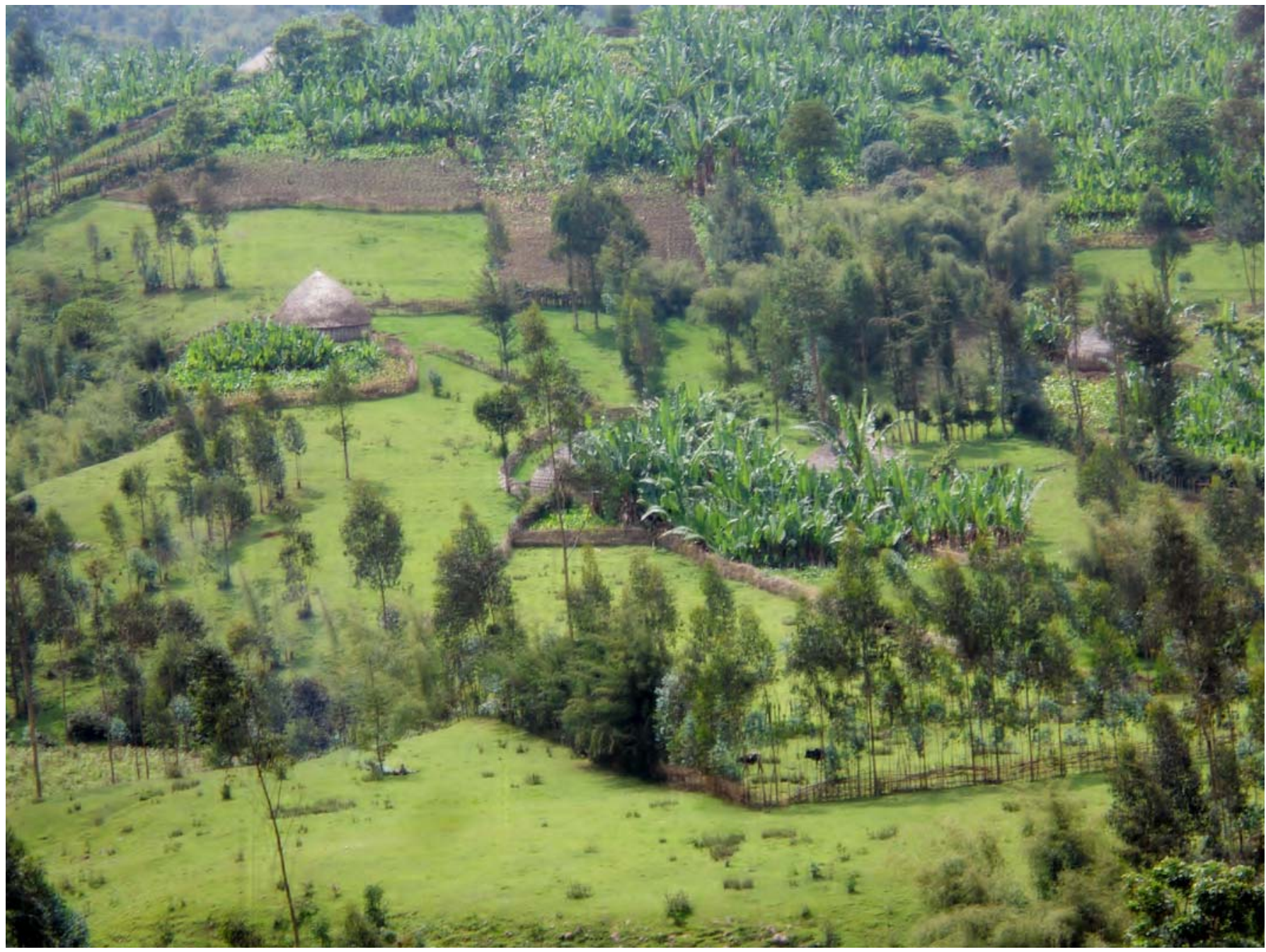

Figure 1. Landscape in Sidama zone showing five houses (left-rear and four across the center) with their fenced enset gardens and pasture areas. Photo by Robert Quinlan.

credit as being good for cattle (Smeds 1955). Grazing land is limited by the relatively high rural population, however, such that enset is an essential fodder (Asfaw and Ågren 2007, Brandt et al. 1997). Livestock eat the parts of enset plants that humans do not eat (leaves and outer stems), which also contain the most protein in the plant (Yilma 2001). The waasa starches that comprises the primary Sidama food are low in protein, however Sidama consume cows' milk, such that enset cow-fodder indirectly fuels human protein requirements. Cattle, in turn, fertilize enset through human intervention. Sidama dig trenches that channel livestock run-off from stalls into enset gardens, and women collect the manure to distribute among enset plants (see M. Quinlan et al. n.d.). Highland Sidama cultivate plants besides enset, including some barley (Hordeum vulgare L.), fruits and vegetables, African highland bamboo (Yushania alpina (K.Schum.) W.C.Lin) and eucalyptus (Eucalyptus globulus Labill. and E. camaldulensis Dehnh.) trees for construction and repair of traditional houses and fences, and they may grow coffee or khat (chat in Ethiopia) to sell (i.e., Coffea arabica L. and Chata edulis Forssk., both native stimulants). Sidama raise smaller livestock including goats (Arsi-Bale Rift Valley goat, Capra aegagrus hircus), sheep (Ethiopian menz and horro breeds of fat-tail sheep, Ovis aries), and chickens (Gallus gallus domesticus), which are mostly for consumption (Asfaw \& Agren 2007). Nevertheless, enset and cattle dominate Sidama subsistence and cultural values (Hamer 1987).

Sidama call an enset garden a weesete gate, or simply gate. Gate range from $1 / 4$ hectare to $1 \frac{1}{2}$ hectares (Tesfaye 2008). As enset takes at least five years to mature, gardens contain plants of various ages and 
sizes. Sidama language has at least ten terms referring to enset age-stages ${ }^{4}$ (Tesfaye 2008). Larger adult plants are closest to the house due to transplantation.

Compared to other societies in the enset complex, the Sidama maintain more plant varieties in their gardens (Bizuayehu 2008, Smeds 1955, Tesfaye 2008, but see Shigeta 1990 for the Ari enset diversification technique). Tesfaye (2008) finds that Sidama gardens contain 5-15 varieties of enset with increasing diversity as garden size and hectares per household member increase. Sidama report that maintaining mixed enset varieties is important to best provide varied materials for numerous enset products they use in subsistence, tools, aesthetics and religion; and to ensure a continued and flexible yield of waasa through varied weather conditions, timing and pest invasions. Although there are five varieties of enset that are abundant across Sidama gardens (gantichcha [gantica in IPA], midashsho [midašo], guulummo [gúlumo], dammala [damala], and daraasi ado [därasi ado]), individual gardens tend to limit their plantings to two of these common varieties, planted with three or more of the rarer varieties (Tesfaye 2008).

Although not ethnobiological classification per se, the most mentioned distinction that Sidama farmers make regarding kinds of plants, is to distinguish between gide, domestic plants, and dubo, wild plants. Gide actually refers to planted garden plants, while dubo refers collectively to forest plants, weeds, and domestic species growing as escapes. People usually speak of enset (weesho, [wešo] enset [singular]) as a gide, although dubbo weese (wild ensets) exist as both escapes and undomesticated forms.

\section{Sidama Classification of Enset}

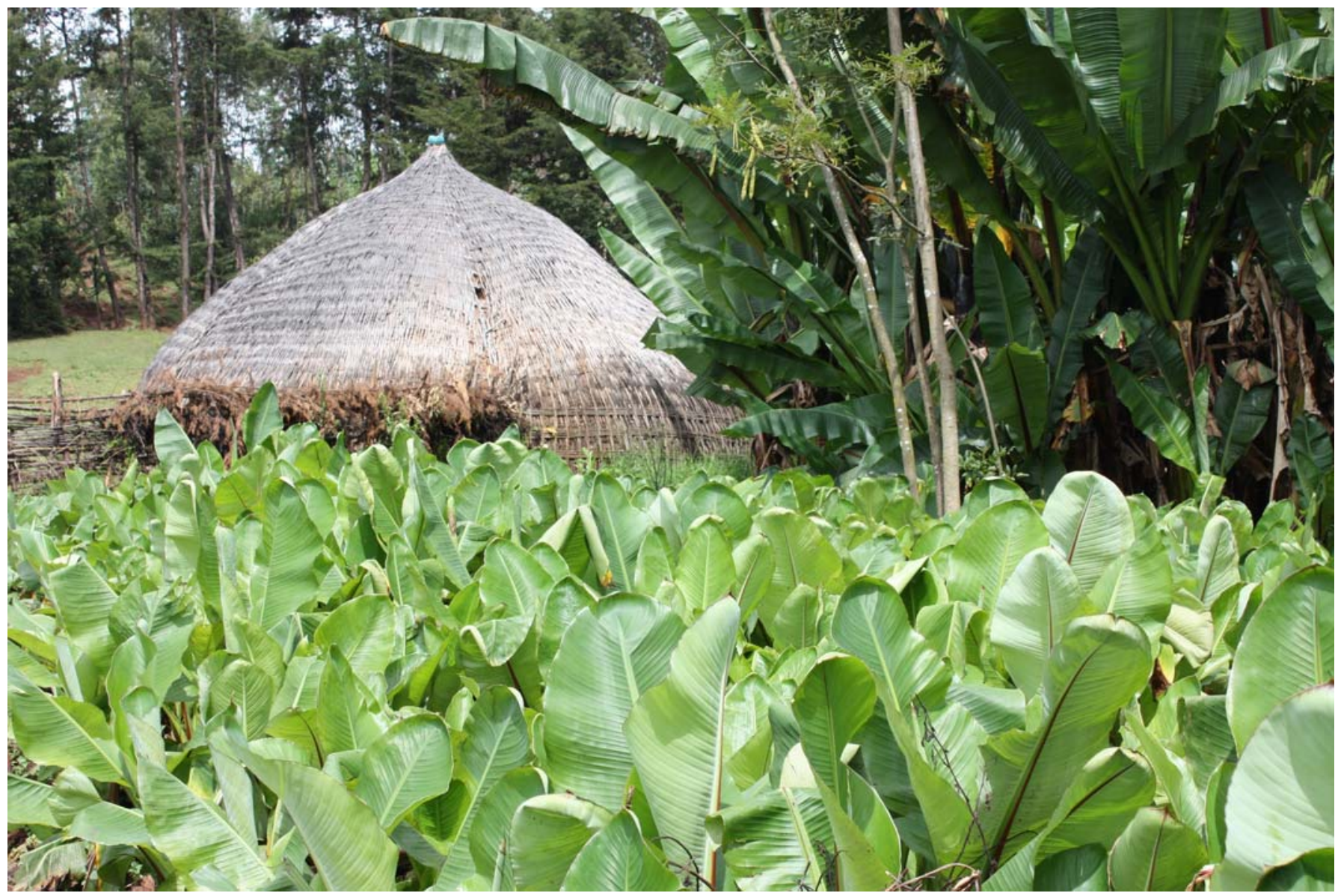

Figure 2. A Sidama house and enset garden. In the foreground are young enset plants, about one year old, called qaxalo. In the rear-right are more mature plants, about four years old, called malancho or itancho. On the left side, behind the house, a piece of the yard/pasture is showing, bordered by eucalyptus in the rear. This vantage obscures that the yard is about one acre (the household has other grazing land as well). Photo by Marsha Quinlan. 


\section{(f) Ethnobiolocy Letters $\quad$ Perspective}

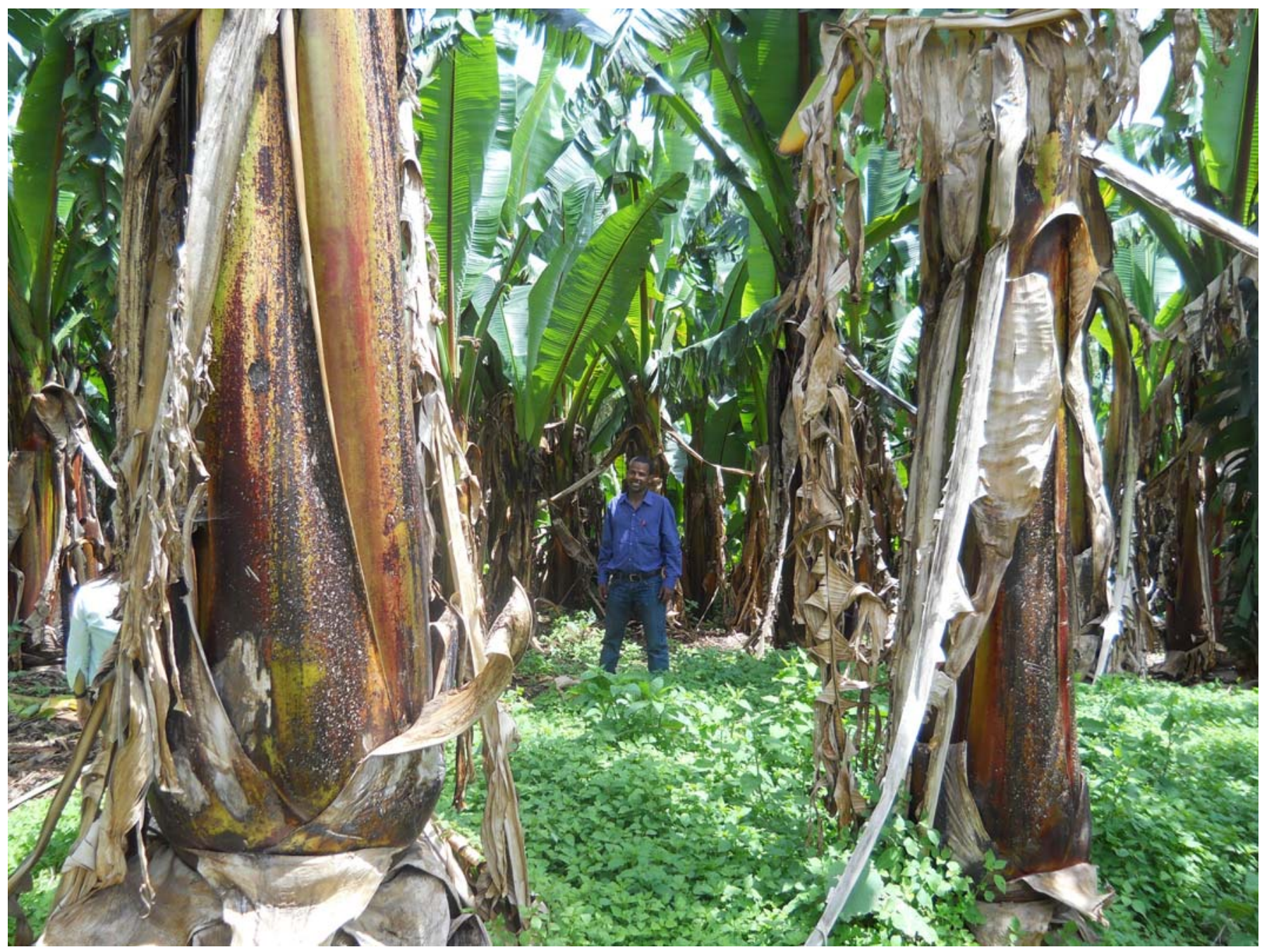

Figure 3. Samuel Jilo Dira (1.72m [5' $\left.{ }^{\prime \prime}\right]$ in height) walking/standing in an enset garden. Photo by Robert Quinlan.

As a species, enset morphology is highly variable and although the extent of its variation remains unknown, researchers document that Ethiopian enset farmers recognize and name many enset varieties or cultivars (Admasu and Struik 2002, Bizuayehu 2008, Shigeta 1990, Tesfaye 2008).

Bizuayehu (2008) found that Sidama collectively named 103 different enset taxa, with individuals naming between five and thirty-five taxa. Nine enset breeds $(8.7 \%$ of those named collectively) were of common knowledge, as more than $50 \%$ of Sidama knew the terms across ten Sidama villages. There are another 59 kinds that a large minority (over 10\%) of Sidama know. Fourteen taxa were named by single informants.

Sidama enset taxa fall into categories, which Bizuayehu (2008) addresses with the botanical terms "supra-variety, variety, and sub-variety." Classification per Berlin's (1992) folk biological classification terms would differ.

At the unique beginner or kingdom rank, Sidama language identifies all plants with the term mu'ro. Sidama also have two (perhaps three) life-form classifications. Sidama generally divide plants into either a haqqe (bakee) or hayiso, i.e., "tree" or "grerb" (sensu Brown, e.g. 1977, 1984), in which haqqe (tree) is a joint category for woody trees and shrubs, and bayiso (grerb) is a joint grass and herbaceous plant category. Enset, (weesho [weřo, singular], weese [wese, plural]), however, is neither haqqe nor hayiso. Martin (2004) warns that, in the Berlinian system, some generics that are "morphologically distinct or economically important plants may be unaffiliated or independent of all lifeforms (p. 216)." Indeed, in this case, weese (enset), are simultaneously herbaceous, as with hayiso 
Table 1. Characteristics of Sidama "male" and "female" intermediate enset types.

\begin{tabular}{lll}
\hline Characteristic & Labbaahu (male) & Meyati (female) \\
\hline Aerial plant size & Larger & Smaller \\
Corm size & Larger & Smaller \\
Edible stem pulp quality & Harder & Softer \\
Corm texture & Tougher & Softer \\
Corm taste & Bitter & Sweet \\
Corm attractive to pests? & No & Yes \\
Processing work & Difficult & Easy \\
Fermenting time & Long & Short or absent \\
Aerial plant vulnerable to predators? & No & Yes \\
"Strength" in environmental stress & Strong & Vulnerable \\
\hline
\end{tabular}

[grerbs]) and large, like haqqe, trees. Perhaps this unique morphology makes enset neither a 'tree' nor 'grerb,' or perhaps their singular economic importance sets them apart from other plants. Sidama informants told S.J.D, however, that weese (ensets), are their own type of mu'ro (plant). It appears, here, that Sidama regard ensets as a special life-form.

In Sidama, weesho (enset [singular], or weese [plural]) generally refers to the edible species of enset (i.e., E. ventricosum). Weesho can serve as a single "generic" kind of plant in reference to, for example, all "plants" (mu'ro), or "crops" (gide), or when Sidama refer, as they normally do, to their gidenna weese, meaning "enset and crop." Because enset is a domesticated species with a great deal of specificity in types, "generic elevation" (Hunn 2013) occurs. Weesho becomes like a life-form in that there are three further levels of specificity recognized with respect to "kinds of enset."

Sidama language has two intermediate taxa, between the term weesho as a life-form, and generic breed terms for ensets. All ensets are classified as either labbaahu (la'bahu), "male," or meyati (meäti), "female." These are symbolic, metaphorical gender terms as enset plants are hermaphroditic. The "male" or "female" attribution has to do with both size differences in plant morphology and with food qualities (see table 1). Meyati, "female" ensets, are smaller than the labbaahu , "male" enset types. "Female" varieties have sweet, softer pulp, which is easier to prepare than that of the "male" types. Some meyati pulp can be boiled and eaten directly, others need fermentation, but less of it than that of the labbaabu plants. The "male" labbaabu varieties have larger, tougher corms, which are fibrous and bitter, unattractive to pests, difficult to process, and require more fermentation than meyati corms. Meanwhile, the meyati "female" enset plants are more prone to predation (e.g., from porcupines), and they are "weaker," i.e. more sensitive to drought, wind, and frost. Despite the extra work involved and less appealing taste, labbaabu are a safer investment due to their size and relative hardiness, so, while Sidama farmers plant both meyati and labbaabu in each garden, labbaahu dominate (Bizuayehu 2008, Tesfaye 2008). The Sidama "male" and "female" enset dichotomy is reminiscent of the ethnobiological classification of domesticated manioc (Manihot esculenta Crantz) among lowland South Americans in that "bitter" varieties protect against pests (McKey et al. 1993) and are therefore prominent in indigenous gardens (Arroyo-Kalin 2010). Another similarity is that Aguaruna Jivaro also classify manioc cultivars according to fermentation requirements; in their case either for "beer-making" (fermenting) or "eating" (not fermenting) (Boster 1984).

We see in table 1 that the intermediate rank classification of meyati and labbaabu appears to reflect a perceptual/morphological distinction (in size and durability of the members). But there is also a related functional distinction from a human-use perspective (Anderson 2011:5), giving those taxa elements of a "special purpose" classification (Hunn, 1982, 2013) (as with watch-dogs in Hunn's 2013 dog example).

Sidama use the word, sircho (sirco, breed, also seed or lineage) to describe the "generic" level kinds of enset. Bizuayehu (2008) finds that generic terms for enset breeds are mostly $(94.2 \%)$ uninominal (as expected in generic terms [Berlin 1992]), though there are some binomials. Most of the generic enset names describe plant morphology. For example, the breed called ado ("milk") has relatively pale leaves and a white corm, while the one called ambooma (am'bôma), 


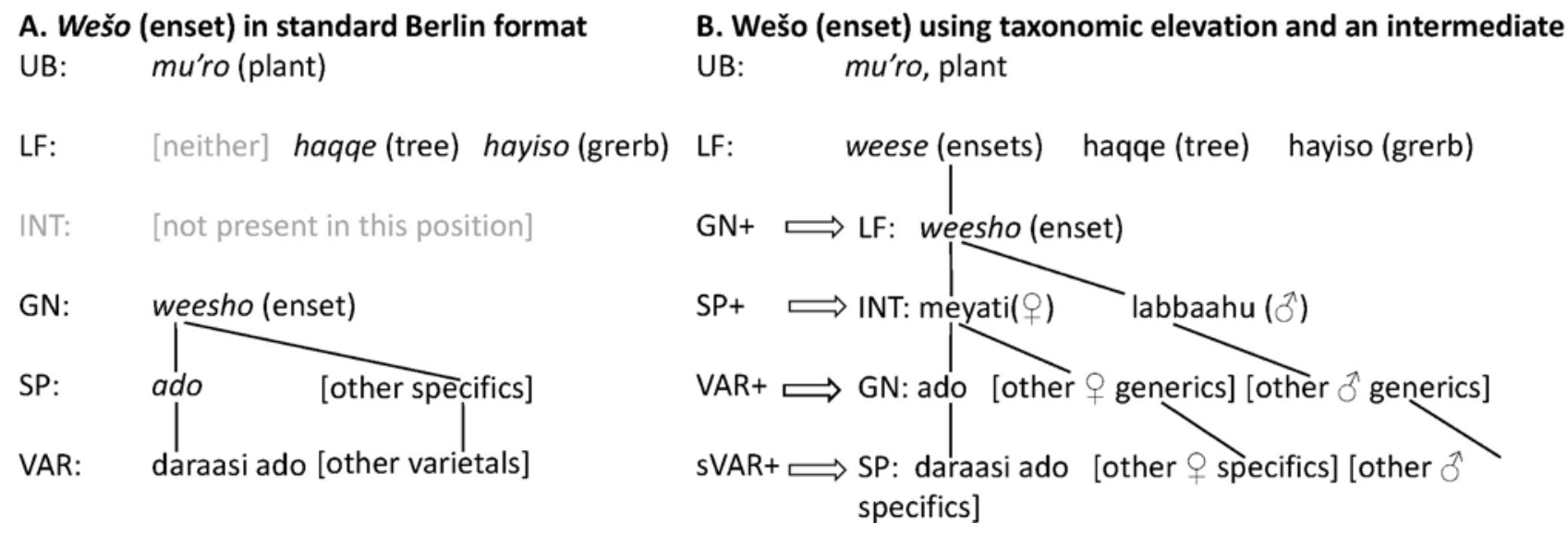

Figure 4. Sidama classification of enset in standard taxonomic representation (A) and using taxonomic elevation (B). Taxonomic elevation allows for the detail present in Sidama language.

"hyena," has black spots on its leaves and petioles. In Bizuayehu's (2008) inventory, more than half of the breeds had names describing the morphology, while non-morphological generic names refer to either growing habit or are names for individuals or groups of people (generally marking regional distributions).

According to Bizuayehu (2008) there are six sub -varieties, which we reckon as "specific" taxa. Specifics all have binomial names comprised of a common generic and a prefix or suffix to modify the specific. For example, darassi ado, is a specific subtype of the ado breed. This pattern shows the hierarchical relationship between the generic and its subordinate specific taxa.

Compared to the standard Berlinian representation (figure 4A), taxonomic elevation (figure 4B) appears to best reflect the cognitive and linguistic processes of Sidama speakers. It allows generic and specific ranks to fall neatly into the Berlinian system, allowing for the "intermediate" rank to fall, as expected, between the "life form" and "generic" ranking 5. Folk taxonomies are thus "flexible cognitive mechanisms" (Hunn 2013) that can conform to cultural contexts (such as breeding). In the Sidama example, weesho (enset [singular]) remains a generic taxon in the context of the domain mu'ro (plants). However, when the cultural domain at hand becomes weese (ensets [plural]), then weesho (enset) comes to resemble-or is elevated to- the rank of life-form, which allows Sidama speakers to focus on the intermediate (labbaabu "male" or meyati "female"), the generic sircho (breeds), and the specific sub-breeds.

Though the modules (taxonomic ranks) of the Berlinian system may be universal (Berlin 1992, Brown 1984), cultures differ ethnoscientifically. Languages may hence omit, expand or shift taxonomic ranks to deal with cultural needs for specificity in taxa, which are utilitarian (Hunn 1982). The more useful a life-form is within a culture, the more experience members have with it, the more the diversity-based ethnobiological reasoning occurs $^{6}$ (Coley et al. 1996). A species' usefulness to a society impacts individuals' emotions regarding the organism, which, in turn, reinforce management of that resource (Anderson 1996). Emotions about life-forms also impact language such that ethnobiological specificity reflects cultures' shared emotions (appreciation or disdain) for organisms (Nolan and Robbins 2001, Nolan et al.2006). The enset lexicon is utilitarian indeed. Enset is essential to Sidama agro-pastoralism; human and livestock survival depend on it. Generic elevation offers further magnification of the descriptive ability of generic and specific nomenclature for enset. Such specificity is important within cultures of the enset complex, and especially for the highland Sidama.

\section{Acknowledgements}

This work was funded through a Washington State University College of Arts and Sciences seed grant for the Initiative for Global Innovation Studies. We thank the School of Behavioral Sciences' Anthropology Program at Hawassa University, especially Walelign Tadesse Robele and Amalo Sooge, for general advice 
and cooperation. We are grateful to Eugene Hunn for advice on this ethnobiological classification analysis.

\section{Declarations}

Permissions: Washington State University Institutional Review Board.

Sources of funding: Washington State University College of Arts and Sciences.

Conflicts of interest. None declared.

\section{References Cited}

Admasu, T. and P. C. Struik. 2002. Analysis of Enset (Ensete ventricosum) indigenous production methods and farm-based biodiversity in major growing regions of Southern Ethiopia. Experimental Agriculture 38:291-315.

Anderson, E. N. 1996. Ecologies of the Heart: Emotion, Belief and the Environment. Oxford University Press, New York, NY.

Anderson, E. N. 2011. Ethnobiology: Overview of a Field. In Ethnobiology, edited by E. N. Anderson, D. M. Pearsall, E. S. Hunn and N. J. Turner, pp.1-14. Wiley-Blackwell, Hoboken, NJ.

Arroyo-Kalin, M. 2010. The Amazonian Formative: Crop Domestication and Anthropogenic Soils. Diversity 2:473-504.

Asfaw, Z. and G. I. Ågren. 2007. Farmers' Local Knowledge and Topsoil Properties of Agroforestry Practices in Sidama, Southern Ethiopia. Agroforestry Systems 71:35-48.

Berlin, B. 1973. The Relation of Folk Systematics to Biological Classification and Nomenclature. Annual Review of Systematics and Ecology 4:259-71.

Berlin, B. 1992. Ethnobiological Classification: Principles of Categorization of Plants and Animals in Traditional Societies. Princeton University Press, Princeton, NJ.

Berlin, B., D. E. Breedlove and P. H. Raven. 1966. Folk Taxonomies and Biological Classification. Science 154:273-5.

Berlin, B., D. E. Breedlove and P. H. Raven. 1973. General Principals of Classification and Nomenclature in Folk Biology. American Anthropologist 75:21442.

Bezuneh, T. 1971. The Role of Musaceae in Ethiopian Agriculture I. The Genus Ensete. Acta Horticulturae (ISHS) 21:97-100. Available at: http:// www.actahort.org/books/21/21_16.htm. Accessed in January, 2014.

Bezuneh, T. and A. Feleke. 1966. The Production and Utilization of the Genus Ensete in Ethiopia. Economic Botany, 20:65-70.

Bizuayehu, T. 2008. On Sidama Folk Identification, Naming, and Classification of Cultivated Enset (Ensete ventricosum) Varieties. Genetic Resources and Crop Evolution 55:1359-1370.

Boster, J. S. 1984. Classification, Cultivation, and Selection of Aguaruna Cultivars of Manihot esculenta (Euphorbiaceae). Advances in Economic Botany 1:3447.

Brandt, S. A., A. Spring, C. Hiebsch, J. T. McCabe, E. Tabogie, M. Diro, G. Wolde-Michael, G. Yntiso, M. Shigeta and S. Tesfaye. 1997. The "Tree Against Hunger": Enset-Based Agricultural Systems in Ethiopia. American Association for the Advancement of Science, Washington, D.C.

Brown, C. H. 1977. Folk Botanical Life-Forms: Their Universality and Growth. American Anthropologist 79:317-342.

Brown, C. H. 1984. Language and Living Things: Uniformities in Folk Classification and Naming. Rutgers University Press, New Brunswick, NJ.

Brown, C. H. 1985. Mode of Subsistence and Folk Biological Taxonomy. Current Anthropology 26:43-62.

Brown, C. H. 1986. The Growth of Ethnobiological Nomenclature. Current Anthropology 27:1-19.

Brown, C. H. 1987. The Folk Subgenus: A New Ethnobiological Rank. Journal of Ethnobiology 7:181192.

Coley J. D., D. L. Medin, J. B. Proffitt, E. Lynch and S. Atran. 1996. Inductive Reasoning in Folkbiological Thought. In Folkbiology, edited by D. L. Medin and S. Atran, pp.205-232. MIT Press, Cambridge, MA.

CSAE (Central Statistical Agency of Ethiopia). 2013. Population and Housing Census Report-Country 2007. Central Statistical Agency, 2010-07, English. Central Statistical Agency, Addis Ababa. Available at: http://www.csa.gov.et/index.php/2013-02-2014-51-51/2013-04-01-11-53-00/census-2007. Accessed on June 20, 2014.

Hamer, J. H. 1987. Humane Development: Participation 
and Change among the Sadama of Ethiopia. University of Alabama Press, Tuscaloosa, AL.

Herskovits, M. J. 1926. The Cattle Complex in East Africa. American Anthropologist 28:230-272.

Hunn, E. S. 1982. The Utilitarian Factor in Folk Biological Classification. American Anthropologist 84:830-847.

Hunn, E. S. 2013. "Dog” as Life-form. In Explorations in Ethnobiology: The Legacy of Amadeo Rea, edited by M. Quinlan and D. Lepofsky, pp. 141-53. Society of Ethnobiology, Denton, TX.

Hunn, E. S. and C. H. Brown. 2011. Linguistic Ethnobiology. In Ethnobiology, edited by E. N. Anderson, D. M. Pearsall, E. S. Hunn and N. J. Turner, pp. 319-334. Wiley-Blackwell, Hoboken, NJ.

Martin, G. J. 2004. Ethnobotany: A Methods Manual. Earthscan, Sterling, VA.

McKey, D. and S. Beckerman. 1993. Chemical Ecology, Plant Evolution and Traditional Manioc Cultivation Systems. In Tropical Forests, People and Food: Biocultural Interactions and Applications to Development, edited by C. M. Hladik, A. Hladick, O. F. Linares, H. Pagezy, A. Semple, and M. Hadley, pp. 83-112. Parthenon, Carnforth, UK, and UNESCO, Paris, France.

Murdock, G.P. 1959. Africa: Its People and their Culture History. McGraw Hill, New York, NY.

Nolan, J. M., K. E. Jones, K. W. McDougal, M. J. McFarlin and M. K. Ward. 2006. The Lovable, the Loathsome, and the Liminal: Emotionality in Ethnozoological Cognition. Journal of Ethnobiology 26:126-138.

Nolan, J. M. and M. C. Robbins. 2001. Emotional meaning and the cognitive organization of ethnozoological domains. Journal of Linguistic Anthropology 11:204-249.

Pijls, L. T. J., A. A. M. Timmer, Z. Wolde-Gebriel and C. E. West. 1995. Cultivation, Preparation and Consumption of Ensete (Ensete ventricosum) in Ethiopia. Journal of the Science of Food and Agriculture 67:1-11.

Quinlan, M. B., R. J. Quinlan, S. J. Dira, M. Caudell, A. Sooga and A. A. Amzye. n.d. Enset Reliance, Change to Maize, and Concepts of Productivity among the Sidama of Ethiopia. (Unfinished ms.).
Quinlan, R. J., M. B. Quinlan, S. J. Dira, M. Caudell, A. Sooga and A. A. Amzye. n.d. Vulnerability and Resilience of Sidama Enset and Maize Farms in Southwestern Ethiopia. (Under review).

Rahmato, D. 1995. Resilience and Vulnerability: Enset Agriculture in Southern Ethiopia. Journal of Ethiopian Studies 28:23-51.

Shack, W. A. 1963. Some Aspects of Ecology and Social Structure in the Ensete Complex in Southwest Ethiopia. The Journal of the Royal Anthropological Institute of Great Britain and Ireland 93:72-79.

Shack, W. A. 1966. Gurage: A People of the Ensete Culture. Oxford University Press, London.

Shank, R. and C. Ertiro. 1996. A Linear Model for Predicting Enset Plant Yield and Assessment of Kocho Production in Ethiopia. Report to United Nations Development Programme, World Food Programme, Emergencies Unit for Ethiopia.Available at: http://www.africa.upenn.edu/ eue_web/ENSET96.DOC. Accessed on May 20, 2014.

Shigeta, M. 1990. Folk In-situ Conservation of Ensete (Ensete ventricosum [Welw.]E.E. Cheesman): Towards the Interpretation of Indigenous Agricultural Science of the Ari in Southwestern Ethiopia. African Study Monographs 10:93-107.

Simmonds, N. W. 1962. The Evolution of Bananas. Longman, London.

Smeds, H. 1955. The Ensete Planting Culture of Eastern Sidamo. Acta Geographica 13:1-39.

Tesfaye, B. 2008. The Enset (Ensete ventricosum) Gardens of Sidama: Composition, Structure and Dynamics of a Traditional Poly-Variety System. Genetic Resources and Crop Evolution 55:1347-1358.

Vavilov, N. I. 1951. The Origin, Variation, Immunity and Breeding of Cultivated Plants. Chronica Botanica 13:1-366.

Westphal, E. and J. M. C. Westphal-Stevels. 1975. Agricultural Systems in Ethiopia (No. 826). Agricultural Research Report, Centre for Agricultural Publishing and Documentation, Wageningen, Netherlands.

Yilma, T. 2001. Coffee-Enset-Livestock Interaction for Sustainable Livelihood in the Sidama area of Southern Ethiopia. International Conference on 
African Development Archives. Paper 39. Available at: http://scholarworks.wmich.edu/ africancenter_icad_archive/39. Accessed on May $15,2014$.

\section{Biosketches}

Marsha B. Quinlan is an environmental and medical anthropologist with foci largely at the intersections of ethnobotany and ethnozoology with health. Her fieldwork has been in North and South America, the Caribbean, and, most recently, in East Africa (Tanzania and Ethiopia). She is an Associate Professor at Washington State University in Pullman, Washington, USA, in the Department of Anthropology.

Robert J. Quinlan is Associate Professor of Anthropology at Washington State University. He is generally interested in ecological and medical anthropology, with specific focus on household demography and livelihood among East African small-holders. His most recent collaborative research focuses on vulnerability and resilience among agro-pastoralists in SW Ethiopia. He has also conducted recent research concerning Maasai veterinary ethnomedical practices in Northern Tanzania. He teaches graduate courses in quantitative analysis, human behavioral ecology, ethnography, and social-ecological systems.

Samuel Jilo Dira is a Doctoral Candidate at Washington State University in the Department of Anthropology, and Lecturer in the Department of Behavioral Science, Hawassa University, Hawassa, Ethiopia. His interests are in ecological and development anthropology, particularly of East Africa. He works in Ethiopia where he applies social-ecological system approaches to cultural resili- ence and adaptation, and biocultural approaches to social learning and ecological knowledge transmission.

\section{Notes}

1Synonyms are Musa ensete Gmel. and Ensete edule (Gmel.) Horan.

${ }^{2}$ Funded by a seed grant from Washington State University College of Arts and Sciences Initiative for Global Innovation Studies to R. Quinlan and T. Rotolo.

${ }^{3}$ Synonyms are Bos indicus and Bos taurus indicus.

4Sidama enset age-stage terms are sima (0-3 month), funta (4-12 month), kasho (kašo in IPA, 2nd year), qatalo or mogicho (katalo or mogichl, 3rd year), simancho (simanco, 4th year), mallancho (malanclc $c$, 5th year), itancho (itanclć, 6th year), bindicho (bindiclč, 7th year, or nearly final maturity), qalimmo (kalimic, $4^{\text {th }}-10$ th year, i.e., final maturity till death. Flowering and seed time varies depending on the breed, manure availability and elevation.).

${ }^{5}$ Brown (1987) noted a similar function with the "folk subgenus."

${ }^{6}$ Diversity-based reasoning may depend on the species' variability or the mode of propagating it. Hunn (personal communication) notes that, maize in Mexico, despite its paramount role as a nutritional staple, does not exhibit the degree of nomenclatural elaboration of such vegetatively propagated cultivars as manioc, potato, sweet potato, taro, or enset. Perhaps crops that reproduce from seed may exhibit less readily defined and manipulated phenotypic variation. 